\title{
Factor Based Approach to Develop a Framework for Enhancing Students' Employability
}

\author{
Deepti Sharma, Deepshikha Aggarwal and Archana B Saxena \\ Jagan Institute Of Management Studies, Rohini, New Delhi, India \\ Corresponding author email: deeptisharma@jimsindia.org
}

\section{ABSTRACT}

Higher education plays a major role in growth and development of individual as well as the economy. Good higher education leads good placement. There are various factors related to higher education like academic marks, technical test, technical interviews and personal interviews' marks that lead to the better placement. The main purpose of this research paper is to identify the association between different fields of higher education data. This is done by using association rule mining algorithm which will identify the associations and correlation between different data that student should focus upon to get better placement.

KEY WORDS: ASSOCIATION RULE MINING, FREQUENCY PLOT, GRAPH PLOT, HIGHER EDUCATION RELATED FACTORS.

\section{INTRODUCTION}

Education field is developing tremendously during past few years. The face of education is getting change with the growth of professional courses in universities and colleges. There are many colleges in India which are self-financed and not funded by the Government. The competition is to get good number of students in these professional colleges and the main aim of getting them placed after completion of their course. Students also decide and take admission in any course or institute for higher education after seeing its placement record. Today, Institutions are working on towards helping the students in achieving their goal of good placement after completion of their study.

The social and economic growth of a country is directly linked to the education and success of its youth. This is done by using association rule mining algorithm which will identify the associations and correlation between different data that student should focus upon to get better placement.The projects conducted by the students

Biosc Biotech Res Comm P-ISSN: 0974-6455 E-ISSN: 2321-4007

\section{crossef}

Identifiers and Pagination

Year: 2021 Vol: 14 No (9) Special Issue

Pages: 24-27

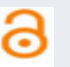

creative

This is an open access article under Creative

Commons License Attribn 4.0 Intl (CC-BY).

DOI: $h t t p: / / d x$.doi.org/10.21786/bbrc/14.9.6
Article Information

Received: $19^{\text {th }}$ Apr 2021

ccepted after revision: $25^{\text {th }}$ June 2021 are also evaluated. The analysis shows that the academic performance is not the only factor influencing the placement of students and these considered factors also play an important role.

\section{Research Strategy and Process}

2.1 Research Process: The research will use association rule mining algorithm. An association rule has two parts. First is antecedent that can be found in the data. Other is consequent which can be found in combination with the antecedent. The purpose of association rules is to enumerate interesting interactions of variables. The association rule is the full expression of the antecedent and consequent together. There are different measures of associations also which are described below:

a.Support: Support shows the frequency of if/then relationship in the dataset. It is defined as the number of times a rule occurs in the data divided by the number of entries in the dataset.

Support $(\mathrm{X}=>\mathrm{Y})=\mathrm{P}(\mathrm{XUY})$

b. Confidence: Confidence is the percentage of transactions when the antecedents are true. It tell about the number of times these relationships have been found to be true. Confidence $(\mathrm{X}=>\mathrm{Y})=$ Support $(\mathrm{XUY}) / \operatorname{Support}(\mathrm{X})$

c. Lift: Lift is measure of performance of a target model at classifying or prediction the cases. It is a rule which measures how many times more likely the consequent 
will occur when antecedent is true compared to how often the consequent occurs on it's own.

$\operatorname{Lift}(\mathrm{X}=>\mathrm{Y})=\operatorname{Confidence}(\mathrm{X}=>\mathrm{Y}) / \operatorname{Support}(\mathrm{Y})$

3. Data Analysis and Implementation: Multivariate mining is used for data analysis and implementation purpose. Multivariate mining is one where there is more than one independent variable for one dependent variable

3.1 Explanation of dataset: Academic_Result_code = It is the code generated from academic marks obtained in three years of MCA course by students.

Technical_Interview= It is the marks obtained in mock technical interviews conducted in the second semester of MCA students.
Tehnical_Test_code $=$ Technical tests are the multi choice tests based on programming languages. They are being conducted for MCA students to make them practise for final placements.

Salary_Grade $=$ It is obtained from the actual salary package of the students at the time of their final placement.

\subsection{Status of variables:}

Independent variable: academic_result_code, tech_test_ code, tech_interview_code, PI_code

Dependent variable: salary_grade

The data set has various fields which are described in the table below.

Table 1. Data Set Fields

\begin{tabular}{|l|c|}
\hline Field name & Description \\
\hline Student_id & Unique ID of the student \\
\hline Academic_result-code & Code given for average marks of three years' academic subjects \\
\hline Tech_test_code & Code assigned for technical tests \\
\hline Tech_interview_code & Code assigned for technical interviews \\
\hline PI_code & Code assigned for personal interviews \\
\hline Salary-grade & Grades assigned for salary \\
\hline
\end{tabular}

Table 2

\begin{tabular}{|c|c|c|c|c|}
\hline Rule No & Rule & Support & Confidence & Lift \\
\hline 1 & $\{$ PI_code $\} \Rightarrow$ Tech_test_code $\}$ & 0.5882353 & 0.7692308 & 0.9340659 \\
\hline 2 & $\begin{array}{l}\{\text { Tech_interview_code }\} \Rightarrow \\
\{\text { PI_code }\}\end{array}$ & 0.4117647 & 0.8750000 & 1.1442308 \\
\hline 3 & $\begin{array}{l}\{\text { Tech_interview_code }\} \Rightarrow \\
\{\text { Tech_test_code }\}\end{array}$ & 0.3529412 & 0.7500000 & 0.9107143 \\
\hline 4 & 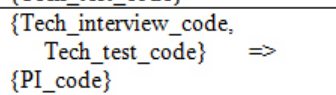 & 0.2941176 & 0.8333333 & 1.0897436 \\
\hline 5 & $\begin{array}{l}\{\text { PI_code, } \\
\text { Tech_test_code }\} \\
\{\text { Tech_interview_code }\}\end{array} \Rightarrow$ & 0.2941176 & 0.5000000 & 1.0625000 \\
\hline 6 & $\begin{array}{l}\{\text { Salary_grade }\} \\
\{\text { Tech_test_code }\}\end{array} \quad \Rightarrow$ & 0.1764706 & 1.0000000 & 1.2142857 \\
\hline 7 & $\begin{array}{l}\{\text { Academic_result_code }\} \Rightarrow \\
\{\text { Tech_interview_code }\}\end{array}$ & 0.1764706 & 1.0000000 & 2.1250000 \\
\hline 8 & $\begin{array}{l}\{\text { Academic_result_code }\} \Rightarrow \\
\{\text { Tech_test_code }\}\end{array}$ & 0.1764706 & 1.0000000 & 1.2142857 \\
\hline 9 & $\begin{array}{l}\text { \{Academic_result_code, } \\
\text { Tech_interview_code }\} \Rightarrow \\
\{\text { Tech_test_code }\}\end{array}$ & 0.1764706 & 1.0000000 & 1.2142857 \\
\hline 10 & $\begin{array}{l}\text { Academic_result_code, } \\
\text { Tech_test_code }\} \\
\{\text { Tech_interview_code }\}\end{array} \Rightarrow$ & 0.1764706 & 1.0000000 & 2.1250000 \\
\hline 11 & $\{$ PI_code $\} \Rightarrow\{$ Salary_grade $\}$ & 0.1176471 & 0.6666667 & 0.8717949 \\
\hline 12 & $\begin{array}{l}\{\text { Academic_result_code }\} \Rightarrow> \\
\{\text { PI_code }\}\end{array}$ & 0.1176471 & 0.6666667 & 0.8717949 \\
\hline 13 & $\begin{array}{l}\{\text { PI_code, } \\
\text { Salary_grade }\} \\
\{\text { Tech_test_code }\}\end{array} \quad \Rightarrow$ & 0.1176471 & 1.0000000 & 1.2142857 \\
\hline 14 & $\begin{array}{l}\{\text { Academic_result_code, } \\
\text { PI_code } \Rightarrow \\
\{\text { Tech_interview_code }\}\end{array}$ & 0.1176471 & 1.0000000 & 2.1250000 \\
\hline 15 & $\begin{array}{l}\text { \{Academic_result_code, } \\
\text { PI_code, } \\
\text { Tech_interview_code }\} \Rightarrow \\
\{\text { Tech_test_code }\}\end{array}$ & 0.1176471 & 1.0000000 & 1.2142857 \\
\hline
\end{tabular}




\begin{tabular}{|c|c|c|c|c|c|}
\hline chiSquared & hyperLift & hyperConfidence & leverage & oddsRatio & Phi \\
\hline 1.12087912 & 0.8333333 & 0 & -0.041522 & $-1.48 \mathrm{E}-15$ & -0.25678 \\
\hline 1.02163462 & 0.875 & 0.66470588 & 0.05190311 & $3.50 \mathrm{E}+00$ & 0.2451452 \\
\hline 0.56216931 & 0.75 & 0.08235294 & -0.0346021 & $3.75 \mathrm{E}-01$ & -0.1818482 \\
\hline 0.97721088 & 0.7142857 & 0.05147059 & -0.0449827 & $2.78 \mathrm{E}-01$ & -0.2397561 \\
\hline 0.24271562 & 0.8333333 & 0.44537815 & 0.02422145 & $1.88 \mathrm{E}+00$ & 0.119488 \\
\hline 0.0843254 & 0.7142857 & 0.41937474 & 0.01730104 & $1.33 \mathrm{E}+00$ & 0.0704295 \\
\hline 0.78061224 & 1 & 0.46470588 & 0.03114187 & NA & 0.2142857 \\
\hline 4.09821429 & 1 & 0.91764706 & 0.09342561 & NA & 0.4909903 \\
\hline 0.78061224 & 1 & 0.46470588 & 0.03114187 & NA & 0.2142857 \\
\hline 4.09821429 & 1 & 0.91764706 & 0.09342561 & NA & 0.4647059 \\
\hline 6.67857143 & 1 & 0.97058824 & 0.11418685 & $-2.48 \mathrm{E}+16$ & 0.6267832 \\
\hline 0.19459707 & 0.6666667 & 0.12058824 & -0.017301 & $5.45 \mathrm{E}-01$ & -0.1069901 \\
\hline 0.48571429 & 1 & 0.33088235 & 0.02076125 & NA & 0.1690309 \\
\hline 0.19459707 & 0.6666667 & 0.12058824 & -0.017301 & $5.45 \mathrm{E}-01$ & -0.1069901 \\
\hline 0.55 & 1 & 0.79411765 & 0.06228374 & NA & 0.3872983 \\
\hline 0.43531746 & 0.6666667 & 0.80882353 & 0.06574394 & $7.33 \mathrm{E}+00$ & 0.3784891 \\
\hline
\end{tabular}

Figure 1: Frequency Plot

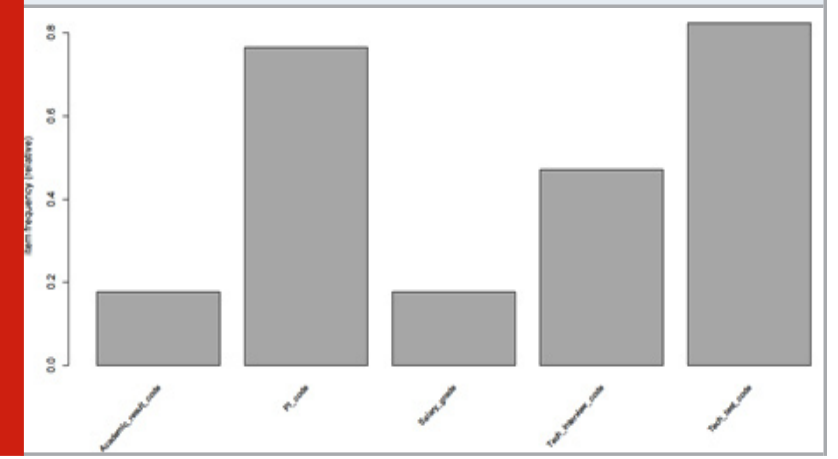

Figure 2: Graph Plot

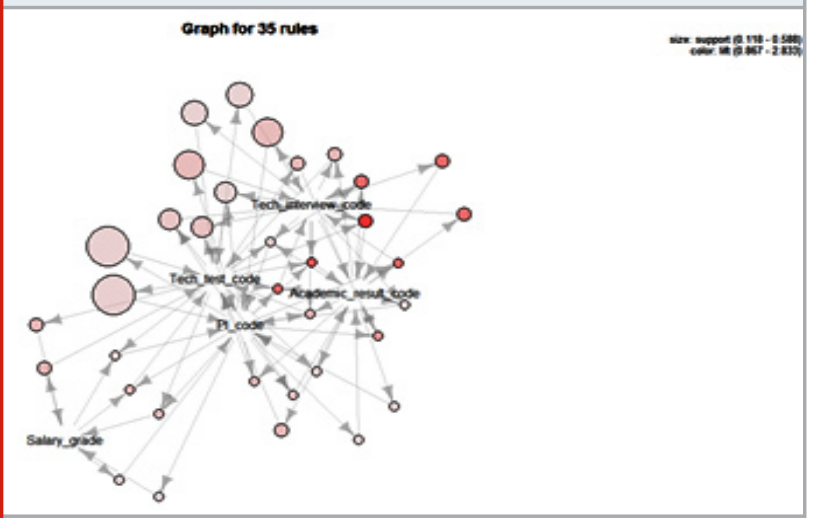

The above data is converted so that we can have the results of academic results, technical test marks, technical interview marks, personal interview marks and salary grade with respect to each student id. Thus the converted dataset will be in the form of \{student_id, salary-grade $\},\{$ academic_result_code, salary-grade\}, \{tech_test_code, salary-grade\}, \{tech_interview_code, salary-grade $\}$, \{PI_code, salary-grade $\}$.

4. Association Mining Rules: The next phase is to create the association mining rules. Based on the dataset, there were many rules which were built. The following table shows few rules with the support, confidence and lift values.

The association mining algorithm has identified more than 35 rules along with the values of support, confidence and lift. But based on potential values of support and confidence, authors are considering only 15 rules and others are removed. Rule 1 PPI_code\} => \{Tech_test_code $\}$ shows the if a student will perform good in Personal interviews, then he will get good marks in technical tests as well. In addition, rule 11 $\{$ PI_code $\}=>\{$ Salary_grade $\}$ states if he performs good in interviews he might will get better salary grade. Also, rule 15 shows the impact of academic results, pi_code and technical interview on technical test marks.

The value of lift is also shown in the above table. If Lift $>1$, variables are positively correlated and for Lift $<1$, variables are negatively correlated. In the above output, out of 15 rules, 11 rules are having lift value greater than 1 which indicates a strong positive correlation among variables.

\section{1 chi-square statistics}

4.2 Frequency plot: A frequency plot is built to show the significance of various independent variables like academic result, personal interviews, technical tests and interviews on the dependent variable placement. It shows the role played of various independent variables in getting the placement in reputed company with a respectable salary grade. 
It can be observed from above figure that the variables PI_code, Tech_test code and Tech_interview_code are most important and in order to get final placement, student must score high marks in these and prepare accordingly.

\section{a. Graph Plot}

It can be identified from the above figure that tech_ test_code, PI_code and academic_result_code are closely associated. Similarly, the academic_result_code, tech_test_code and tech_interview_code are also closely associated.

\section{RESULTS AND CONCLUSION}

In this paper we have analyzed the various academic activities that a student has to go through during the 3 years of MCA technical course. The student is not only assessed on the basis of marks obtained in the end term examination but a regular assessment is carried out in the form of technical tests, technical interviews and non-technical assessments. Domain of the paper is limited to the record of three batches of MCA students of a college in Delhi, India. This dataset is analyzed for the listed objectives and association of dependent variable is identified with various independent variables. It has been noticed during the analysis that marks obtained by the students in combination with the pre placement activities have more association with salary grade or placement package. The current results can be very helpful for academic institutions in planning their course structure and teaching pedagogy as the overall aim of all professional colleges is to make the students employable. The association depicted in this paper can define how variables are related. We have also predicted the behavior of the dependent variable (Salary Grade) by monitoring and manipulating the behavior of the independent variables (Mean Marks, Technical score, and PI marks). Association mining rules are also created. Frequency plot showed the factors which play important role for getting good placement. A graph plot is also made to show the close association between various factors.

\section{REFERENCES}

A. Green, "Placement Testing," Heidelberg, Germany, 2018.
B. Sen, E. ucar and D. Delen, "Predicting and analyzing secondary education placement-test scores: A data mining approach," Expert Systems with Applications, pp. 9468-9476, 10 August 2012.

D. A. D. G. Deepti Sharma, ”Academic Performance Analysis of Information Technology Students in Higher Education Institutions," vol. 8, no. 9s, 2019.

D. S. Deepshikha Aggarwal, "Analysis of the Factors Influencing the Choice of College for Higher Education," vol. 6, no. 9, 2018.

D. S. Deepshikha Aggarwal, "Application of Clustering for Student Result," vol. 7, no. 6C, 2019.

D. Wall, J. C. Alderson and C. Clapham, "Evaluating a placement test," Sage Publication, p. 1, 1994.

Duncan Cramer, Fundamental statistics for social research, London: ROUTLEDGE, 2016.

Fairness and Test Use: The case of the SAT and Writing Placement for ESL students, Columbia, 2006.

G. A. H. Ana Azevedo, "Competency development in business graduates: An industry-driven approach for examining the alignment of undergraduate business education with industry requirements," vol. 10, no. 1, 2012.

L. e. al, "Employability Appraisal Scale (EAS): Development and Validation in a Spanish Sample," vol. 9, 2018.

M. Barbara J, "Criteria for Placement Decisions in Protective Services.," Child Welfare, pp. 367-373, 1984.

S. b. alex tymon, "Improved academic performance and enhanced employability? The potential double benefit of proactivity for business graduates," vol. 10, no. 2, 2016.

S. Chacón, I. Barbero and E. Vila, "Polychoric versus Pearson correlations in exploratory and confirmatory factor analysis of ordinal variables," Quality \& Quantity, pp. 44-153, 2010.

S. D. H. a. B. I. V. d. H. Ans De Vos, "Competency development and career success: The mediating role of employability," vol. 79, no. 2, October 2011.

Z. R. G. C. Maria Elisa Maiolo, "Students' Academic Performance and Employability: A Study on Italian Undergraduates," vol. 19, no. 4, 2013. 